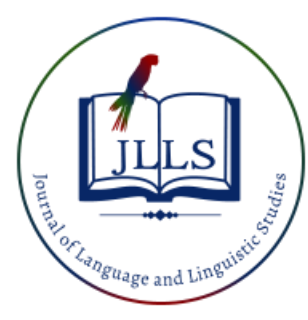

Available online at www.jlls.org

JOURNAL OF LANGUAGE AND LINGUISTIC STUDIES

ISSN: 1305-578X

Journal of Language and Linguistic Studies, 16(4), 2163-2181; 2020

\title{
'Tele-education' in the COVID-19 pandemic process in Turkey: A mental diaspora research specific to Turkish Language Teaching students
}

\author{
Mete Yusuf Ustabulut a ${ }^{\text {iD }}$, Savaş Keskin ${ }^{\text {b }}$ iD \\ ${ }^{a}$ Bayburt University, Bayburt, Turkey \\ ${ }^{b}$ Bayburt University, Bayburt, Turkey \\ APA Citation: \\ Ustabulut, M. Y. \& Keskin, S. (2020). 'Tele-education' in the COVID-19 process in Turkey: A mental diaspora research specific to Turkish \\ teaching students. Journal of Language and Linguistic Studies, 16(4), 2163-2181. \\ Submission Date:05/08/2020 \\ Acceptance Date:09/10/2020
}

\begin{abstract}
This study tries to map educational processes that have to be transformed into the extraordinary history of the COVID-19 pandemic and adapt to the 'new normal' with a relational and metaphoric approach. In the study, the existing physical and mental conditions of the students who are "scattered/dispersed" geographically due to the mandatory "return home" in the pandemic process are conceptualized with the metaphor of the "diaspora". The study aims to draw attention to student-centered social problems by questioning the functionality of tele-education processes, which are designed to compensate for interrupted educational relationships and make them sustainable again. It is aimed to measure the effects of online consciousness that were deterritorialized by human-computer interaction and computer-mediated communication on student performances and to understand student motivations during the tele-education process. Therefore, a survey was conducted at ten universities in Turkey and reached 150 students through the snowball sampling technique. The results of the study show that the student selfperception of the tele-education process coincides with the diasporic identity and this unusual technology integration that cannot be fully compensated triggers mental diaspora feelings.
\end{abstract}

(C) 2020 JLLS and the Authors - Published by JLLS.

Keywords: COVID-19; pandemic; distance education; Turkish Language Teaching; mental diaspora

\section{Introduction}

History, which is one of the names given to the collective adventure of anthropomorphic regulation and control of temporal and spatial existence, is not eternal in terms of ordinariness and sustainable normality. The big events that can establish their own history in the temporal plane covered by the historical system unusually disrupt the structure of humanity and force the fictional life to transform. The Coronavirus event (Di Gennaro et al., 2020; Nadeem, 2020; Şahin et al., 2020), which emerged in Wuhan (China) with a new effect and form, is in the state of establishing its own extraordinary/abnormal/reactive history, It is inevitable to trigger a normalized cultural, sociological and educational transformation Coronavirus, declared as a global pandemic by the World Health

\footnotetext{
${ }^{1}$ Corresponding author.

E-mail address: meteustabulut@bayburt.edu.tr
} 
Organization (WHO, 2020b) and causing the globalizing world to face unpredictable social problems without any boundaries to health, also states the pathological identity of an abnormal history and the traumatic memory of humanity under the name Covid-19 (Cortegiani et al., 2020; Unhale et al., 2020; Yavuz \& Ünal, 2020), in which its typology in viral character and the timing of appearance are encoded. Because, as with any wide-scale 'disaster' history, there is the 'new normality' of a Post-coronavirus period, which symbolizes the impossibility of the return of history to its usual course. This study is the outcome of the aim of mapping 'dispersion/diaspora' as socio-digital and psycho-digital, by degrading the coronavirus-induced problems in the field of education and the curiosity of measuring the effects of social pathology to the content of a 'non-voluntary' and 'unusual/abnormal' tele-education process in higher education. In the study, the use of the concept of 'tele-education' consciously instead of 'distance education', which is a formal concept, is an attempt to emphasize the 'unusual' character of the process and to make the concept of 'distance' specific to the subject with a mediatic adjective.

The educational perspective that makes the concept of university and diaspora part of an equation established in a local, mental, and instrumental context stems from the fact that universities are institutionally cosmopolitan. These cosmopolitan constructions, which include students from different cities and countries, can turn into scattering as well as a central gathering area. For this reason, the state of being diaspora, which evokes a socio-political term, is used in this study to symbolize the digital and mental breakdown of students in the pandemic conditions as a metaphoric situation/event descriptor because this metaphoric conceptualization may be a criterion for evaluating the strong effects of coronavirus on the instrumentalization of education and digital metamorphosis. Due to the coronavirus pandemic, the lockdown (NTV, 2020), which was initiated on March 16, 2020, and supposed to be limited to 3 weeks, has become continuous because of the number of people in plateau situation that is infected, needs intensive care and is intubated. And as an emergency plan, distance education was initiated in most universities within a week (YÖK, 2020). Unlike distance education, which is a proactive interpretation process to new communication technologies (Elitaş \& Devran, 2017) the necessity of conversion of the face-to-face conventional teaching relations to a reactive tele-education format which is maintained entirely by tools, the 'break' from the physical teaching environments that are the " main venue" of higher education has led to the "dispersal" of the students gathered in a single center (university) in different cities of Turkey and has caused the behavior of performing a representative school using digital tools. The 'voluntary obligation' oxymoron used by Elitaş (2018) when defining integration into proactive distance education can be placed in the context of consistency as 'reluctant obligation' in this reactive transition process. As a historical event that prevents the school from being 'the main location' of education, the coronavirus made it necessary to impose a compensatory role as 'over-space links' to distance education by making the teaching process diasporic (Göker, 2015).

The reason for using the diaspora metaphor to describe the situation of students in the tele-education process that began due to the coronavirus pandemic is the possibility of establishing peer-level links between the situations of those who are in a diasporic state subjected to 'forced migration' and the situations of the students who are currently performing 'forced return to home'. Thus, although students returned to their homes, which are their main places as individuals, they had to leave their schools as students. For this reason, the diaspora metaphor mentioned is meaningful when it comes to student awareness and includes organic and digital layers of an identity maintained by tele-education. The etymology of the concept points to the archetypical meaning of 'scattered seeds left and right', which arises from the combination of dia (for, due) and sporos (seed) (Gilding, 2013), while its current counterpart focused on 'breaking away from its physical space and reorganizing in another space' (Elitaş \& Keskin, 2014) can also be expressed. The meaning of the concept meets the efforts of students, who are the builders of an educational process that breaks away from its central physical extent (university), to spread from 'right-to-left', to begin tele-education by reorganizing in 'another' extent, namely digital platforms, and to maintain their focus of educational consciousness through representative actions. Since 
it is not possible to carry the spatial origin (university/school) that leaves traces in the mind and memory, it is the destiny of the diasporic to establish objective links by associating the spirit of this place with the structures in the abode (Ulusoy, 2017). The relationship between student awareness and diasporic consciousness by breaking away from the physical organization that traditionally established it, and the relationship between the representation of tele-education and attempting to remove this awareness from being diasporic, constitutes the mental diaspora state.

Student status, which has turned into a diasporic consciousness due to coronavirus pandemics, can be coded as sets of relationships that also overlap with the features of the concept of diaspora. Some features of the diaspora state theorized by Cohen (1996) can be expressed as follows: (1) dissemination from an original homeland to two or more locations, usually as a result of a traumatic event, (2) a collective memory and myth associated with the homeland, including its territory, achievements, and history, (3) collective commitment to the idealization and protection of the homeland, (4) a collectively approved return dream, (5) incompatibility and problematic relationships with the hosts at the destination as a diaspora, (6) empathy and solidarity with others in the diasporic state in these features, it is possible to reach the diasporic model, which is considered to define the students' situation, when the expression "university/school" is written instead of the expression "homeland" because the codes determined by informal observations and interviews and planned to be tested as the hypothesis of this study overlap with these six properties to a large extent. As a result of a traumatic event (pandemic), the students' leaving school and scattering across the country, preserving their memory and myths about the school, missing the school, their idealization and return requests, their incompatibility in their family homes, and their solidarity with other students in the diasporic state are quite valid reasons to use the diaspora as a conceptual metaphor to explain their situation.

This study, which aims to understand the mental diaspora states of higher education students in pandemic-based tele-education processes, is important in terms of its approach to the comprehensive effects of coronavirus from a metaphorical conceptualization perspective. The mental diaspora status, measured by a questionnaire of 150 students studying in the Turkish Language Teaching Department of 10 state and foundation universities in Turkey, helps to approach student-related problems in the teleeducation process with a different attitude and to provide process designers with a solution.

\subsection{Literature review}

The concept of the diaspora focuses on ethnic elements, such as Jews displaced in contemporary political science and international law studies (Anteby-Yenini \& Berthomiere, 2005; Ben-Rafael, 2010). However, apart from this classical ethno-political understanding, it also includes Africans (victim diaspora), Indians (labor and colonial diaspora), China and Lebanon (trade and business diaspora), and more importantly, the cosmopolitan diasporas of the global era, where deterritorialization is rising (Cohen, 2008), a large number of typical examples can be mentioned. As a matter of fact, according to Ulusoy (2017), diasporas are open to debate with a more common type as a global and hybrid social problem without being limited by ethnicity or the politics of places. Contemporarily, the diaspora is not nation-specific and is a supra-relation, which is established in the description of all kinds of disintegration and association networks.

Castells (2000) states that physical places have become void for individuals who are constantly circulating online as unconditional travelers in the space of flows, and especially bilocation-style philosophical existence situations take place in a digital context. The concept of deterritorialization (Castells, 2008), which is among the ground knowledge of the network society proposition, overrides the dependence of ontological debates (Heidegger, 2011) on the belonging of time/space, such as the uniqueness, terrestrial and singularity of being (Heidegger, 2011). Individuals who are represented numerically by the fundamental principles of the digital culture system can be freely represented in 
virtual flexibility, fluidity, and simultaneous multi-entity performances, leaving the symbolic constraints of representative traditional spaces (Manovich, 2001). The numerical representation, which gives individuals the title of 'digital travelers' (Keskin \& Kaya, 2018), is the virtual reflection of the largescale deterritorialization of the mobile asset. Digital cultural spaces that interlock globally and continue to create converged new spaces are among the strongest reasons for the individual's existence to be explained not by places but by mobility because numerical representations, as Deleuze and Guattari (2005) conceptualize, make 'organic body' impossible by creating 'bodies without organs' and thus the online individual acquires the qualification of 'being everywhere like everyone in the system' (McLuhan \& Powers, 2010). The deterritorialization which is a cornerstone of decentralization and global 'distribution', means the continuous realization of a state of mere diaspora. Ultimately, virtual space involves the existence of individuals who are detached from their original 'homeland' and scattered everywhere. In this case, the diaspora metaphor, which expresses the results of the students' teleeducation, means adaptation to the digital context rather than the modern version and homelessness.

Educational relations, whose instrumental content increased during the compulsory tele-education process, necessarily spread and reorganized the link between the student and the new means of communication. The dominance of instrumental and technical action (Habermas, 1993) in the relational dimension of education has accelerated the maturation of a social problem that can be conceptualized as "digital surroundings." While ordinary distance education, which is designed as sustainable educational relations with new communication technologies, is considered as an integrated secondary method, it has become the basic method and human-computer interaction (HCI) has increased more and more. Strong influences such as the diasporic user profile interacting with the computer system and the transfer of education to a process indirectly by tools, rather than a direct process, involve the risk of making students' mental belonging and educational consciousness inclined towards instrumental thinking because computer-mediated communication (CMC) is among the revolutionary issues frequently discussed in almost all converged cultural forms and in digital transformational education (Hrastinski \& Keller, 2007; Grooms, 2003). While comments on the fact that CMC is an effective opportunity in education are generally focused on the efficiency and the parameters of the process (Ramessur \& Santally, 2007), in this study; the emphasis is given to the increasing possibility of instrumental convergence due to the pandemic and the possibility of integrating students' digital diasporic assets into an advanced mental diaspora.

Discussing the evil effects of virtual representation systems under the title of "mental diaspora of networks", Baudrillard (2005) argues that the mind, which has to be divided/dispersed among an infinite number of networks, works with an artificial form of mechanical thinking. Extreme reasons such as media multiplexing, convergence, and abundance in trans-medium activities fill the content of traditional educational relationships have pluralized the mental and physical disintegration of students in the pandemic process. Thus, the state of health, which is desired to be physically protected with the decision of distance education and 'home care/isolation' precaution, has entered a stalemate due to abuse in mental condition. As a matter of fact, in the definition of WHO (2020a) about health, "physical, social and spiritual well-being" is stated, and in WHO reports (2020c) focusing on pandemic effects, it is stated that coronavirus is a mental health problem. The pandemic process, which diasporically affects students' physical, social, and mental health interactions, creates the complex paradox in the educational sustainability plan, where tele-education is considered as compensation because the sense of belonging, disorganization, and loss of origin (Ulusoy, 2016) of 'diasporic consciousness' is exposed to the 'mental diaspora of networks' due to the deterritorialization of the digital system in which it converges for compensation CMC, which distributes the students mentally to the units that are eternally broken down between vehicles, physical and virtual life, real and surreal experiences, contains mental diasporas that are difficult to compensate for virtual belonging (Elitaş \& Keskin, 2014). 
The specific interests of the studies in the literature, which examine the relationship between education and diaspora, focus on the capacity of classical diasporas to be integrated into the formal education processes of the host countries (Africa-Europe Platform, 2014; Ahmed \& Bradfard, 2011; Bekerman, 2020; Boutte et al., 2017; Lulle, 2015; Carlson \& Hang, 2011; Ferede, 2020; Hosein et al., 2006; Yusuf, 2012). The fact that immigrants and students from ethnic groups in the diaspora are excluded from the problems of harmony and identity conflict and incorporates the mental diaspora, which is a must of online life in the field of education, is the basic contribution of this study to the literature.

\subsection{Research questions}

This research seeks an answer to the main problem of "Does the mental diaspora take place among students during the Tele-Education process due to COVID-19"? The" known "plane that establishes the main problem (unknowns) of the research is coded as an assumption and helps the organization of subproblems for the mental diaspora metaphor. In this organization, the theoretical determinations of Safran (1991) regarding diasporas are taken as reference. According to Safran (1991), (1) diasporic ones are scattered from an original 'center' into two or more 'environmental' regions, (2) maintain a collective memory, vision, or myth about their original center/homeland (physical location, history, and achievements), (3) have adaptation problems due to some disagreements with the host, (4) they see their homeland as their real, ideal home, and they will return as soon as conditions come, and (5) continue to relate to it personally or indirectly. Somehow their homeland, collective consciousness, and solidarity are significantly defined by the existence of such a relationship.

Based on the above statements, item (1) is the obvious symptoms of diaspora, the presence of which has been observed in the process. In this study, the terms' homeland 'or' center 'in the diaspora script are coded as the' physical location of the 'school/university'. Therefore, the situation of "dispersing from the center to the environment" in item (1) coincides with the students' tele-education processes because the school/university continues with the tele-education relationship as compensation for physical disintegration, and thus collective student awareness is kept alive. In order to complement these two assumptions that overlap with the observation, other items identified by Safran will be tested with findings as sub-problems so that the answer to the main problem of whether the students are diasporic or not. In this context, the sub-problems of the study can be expressed as follows:

1. Do the students protect a collective memory and myth related to school/university?

2. Do the students try to establish personal and indirect relationships and collective solidarity?

3. Do the students dream of going back to school/university?

4. Do the students feel the lack of belonging due to the lack of integration in their new environment where tele-education takes place?

Within the framework of the main and sub-problems above, in this study, it is aimed to map the diaspora experienced in the tele-education process originating from Covid-19 physically, digitally, and mentally and to make one of the socio-pathological aspects of the process visible from the student perspective.

\section{Method}

Based on the quantitative dataset, this study covers the students' mental conditions and educational motivations in the pandemic process coded as independent variables and data sources containing the information of the dependent variable (mental diaspora) that is spread over a wide geographic area. The 
insightful reflections of the mental diaspora that takes place within and, as a result, digital representation are expressed numerically.

This study is designed according to the survey model that allows the reading of subjective and insightful data in quantitative research models. The survey model (de Leeuw et al., 2008; Jackson, 2005), which is a frequently used model in the education process and is shaped by the interaction of the subjective approach and contributions of the parties, offers the advantage of numerically structuring the data production between multiple and variable units (individuals). Thus, the measurable and theoretically relatable aspects of amorphous relationships in the process become clear and controlled.

\subsection{Sample}

This study's target population comprises Turkish language teaching department students from the faculties of education at different universities. While the research's target population was determined, the universities in Turkey with faculties of education were reached through academic networks, and 10 of them were selected. Some students were reached with the snowball sampling technique by contacting academicians from the Turkish Language Teaching Departments in the target population, and 150 students were interviewed, 15 students per university. Due to the difficulty of reaching students during the pandemic period, within the framework of the snowball sampling technique applied to make an informal assessment of inter-student networks, contact was made with another unit where each reached unit was a reference. In case of some students' reluctance, an alternative unit is included in the research.

When we look at the demographic components of the sample: firstly, it can be said that the participants were coded as female $(64.7 \%)$ and male $(35.3 \%)$. The fact that the number of female participants is higher than the other is related to the development of accessibility to the units in the snowball sampling process beyond the researcher's control. Secondly, in the demographic findings category, age groups that characterize the students' generation and indirectly symbolize their commitment to the digital system were examined. Accordingly, the participants were included in the categories 18-21 (46.7\%), 22-25 (40.0\%), 26-29 (9.3\%) and 30 years old and above (4.0\%). It can be stated that the $\mathrm{Z}$ and $\mathrm{Y}$ generations of the participants reflect the characteristics more. So they can be referred to as 'digital native', which indicates that they are active agents of the digital system.

The demographic categories of the participants include the gender and age variable as well as their educational levels. It was aimed to represent all levels by distributing at the level of 2 nd class $(32.7 \%)$, 3rd class (32.7\%), 4th class (20.7\%), and 1st class (14.0\%) among the participants. This very demographic category, which is meaningful under the assumption that the students 'self-perceptions of their educational identity will differ according to class levels, can reference the understanding of the relationship that participants will develop with their student identity, schools, and distance education system. Finally, the participants were sought from administrative regions to provide comprehensive representation in the demographic category in the geographical distribution. Accordingly, the geographical view of the diaspora was also reflected by reaching the groups of students residing in Southeastern Anatolia Region (34.0\%), Eastern Anatolia Region (25.3\%), Black Sea Region (13.3\%), Central Anatolia Region (9.3\%), Mediterranean Region (8.7\%), Marmara Region (6.7\%) and Aegean Region (2.7\%). The geographical distribution, which provides the condition of being 'spread over two or more places' (Cohen, 1996), also makes it easy to imagine the 'distance closeness' of the students.

\subsection{Instrument}

In this study, a survey instrument is used to access the data. The survey design (Roberts et al., 2014), which consists of structured multiple-choice, Likert scale and open-ended questions, measures the data related to the framework determined in the research problem. The questionnaire form, a measurement tool, was created digitally as a Google Form due to reasons such as pandemic conditions not allowing 
physical mobilization, transportation problems to the geographically wide sample units, and cost and timeliness. Internet survey (Manfreda \& Vehovar, 2008), which is one of the application areas of the scanning instrument, is also important as a symbolic application that draws attention to the 'instrumental' imperatives of the students in the tele-education process.

\subsection{Data collection and analysis}

In the pilot study conducted in the first phase of the survey implementation, communication-related problems in the data collection process that will take place remotely were identified, and ways of facilitating the participation practice were sought. With the questionnaire form sent via messaging applications, voluntary participation was sought by giving information about the purpose and scope of the research. During the filling out of the questionnaire, the contact with the student was not interrupted and the instantaneous questions were answered simultaneously. The questionnaires collected by getting confirmation from the students were digitally filed with the coding number record.

The data recorded digitally in the Google Drive system and the personal computer were re-coded in the SPSS program and analyzed according to Frequency Analysis, which is one of the Content Analysis types. The data expressed in terms of frequency are transferred to the tables and interpreted.

\section{Results}

In addition to the demographic background, the perceptual reflections of the 'intermittence of the education'(closure of schools) and 'transition to tele-education' decisions, which make students think in the 'forced immigrant' category, were examined. Because their interpretation of 'displacement' conditions and decisions also shows how their diasporic consciousness is shaped, those in a diaspora tend to produce antipathy to administrative mechanisms and decisions and 'natural disasters' that force them to immigrate in general. Opinions of the participants regarding the obligatory decision and the decision that prevents and 'spreads' them from being at school are given in Table 1. below.

Table 1. Compulsory deceleration of students and subjective opinions on Tele-education decision

\begin{tabular}{|c|c|c|c|c|c|}
\hline $\begin{array}{l}\text { Personal Opinions on Tele- } \\
\text { Education Decision }\end{array}$ & 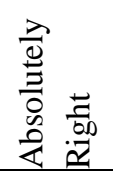 & $\frac{\vec{c}}{\overrightarrow{00}}$ & $\begin{array}{l}\frac{D}{0} \\
\frac{0}{0} \\
\frac{d}{0} \\
\end{array}$ & 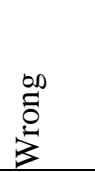 & 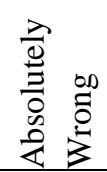 \\
\hline $\begin{array}{l}\text { How do participants evaluate the } \\
\text { decision to take an obligatory break } \\
\text { from education after pandemic? }\end{array}$ & $\% 66,4$ & $\% 24,8$ & $\% 6,7$ & $\% 0,7$ & $\% 1,3$ \\
\hline $\begin{array}{l}\text { How do participants evaluate the } \\
\text { decision to pursue 'distance' in higher } \\
\text { education in the pandemic process? }\end{array}$ & $\% 36,2$ & $\% 32,2$ & $\% 14,8$ & $\% 6,7$ & $\% 10,1$ \\
\hline
\end{tabular}

According to the table, a significant part of the participants $(66.4 \%)$ considers and support the decision to give an obligatory break to post-pandemic education as 'absolutely the right decision'. Similarly, participants (24.8\%) who advocate the correctness of the decision predominate against moderates $(0.7 \%)$ who advocate their mistakes, and participants who have definite attitudes. In this case, it can be stated that the students internalize their status of being diaspora and establish a consensual public opinion that it is a "beneficial" decision by producing reasonable ground. The contingency of the supportive opinions of the participants regarding the 'compulsory break' decision, while continuing in the evaluation of the decision to continue higher education 'remotely' in the pandemic process, also 
shows a proportional decrease $(36.2 \%)$. Along with the increase of the undecided (14.8\%), there is a significant increase in the opinion that the decision is 'absolutely' wrong (10.1\%) and those who report the mistake (6.7\%). This situation may result from the conflict between students 'desire for the sustainable process as compensation for break/breakup and their experience of the traumatic uncertainty of break/breakup consciousness.

'Digitalization in education', which is a future and more abstract conceptual before the pandemic, has not been experienced in such a real and wide scope although concrete 'digital transformation' steps have been taken. Students, who have had the opportunity to experience tele-education, have the opportunity to make rational comparisons between traditional education and digital education now. In this context, the participants were asked about their opinions regarding the design of the ideal education process and the responses are given in Table 2 below.

Table 2. Process plans of students regarding ideal education

\begin{tabular}{ll}
\hline Opinions about ideal process design & \\
\hline Fully physically engaged / traditional & $\% 52,3$ \\
Completely 'remote' and physically unattended & $\% 8,1$ \\
Mixed (physically attended + remote) & $\% 39,6$ \\
\hline
\end{tabular}

An important part of the participants stated that despite the fact that they are from the $\mathrm{Z}$ and $\mathrm{Y}$ generation and familiarity with the digital culture, completely physically attended/traditional education is ideal $(52.3 \%)$. The low rate $(8.1 \%)$, which makes the ideal of distance and physically unattended (teleeducation) process design ideal, might be a sign that the current student profile tends to preserve its traditional gains. However, the effect of the $\mathrm{Z}$ and $\mathrm{Y}$ generation is clearly seen in the participants' mixed process design ideals (39.6\%). While 'traditional' approaches are willing to distinguish sharply between the traditional and the digital, the 'hybrid' individuals of the convergence culture continue to adopt more eclectic and mixed lifestyles.

\section{R.Q.1. Do students protect a collective memory and myth related to school/university?}

Positioned as a characteristic of being a diaspora, the "memory of the homeland and myth" is part of the checklist of conceptual or metaphoric meaning efforts. In this sense, in order to understand whether students are in diasporic condition, it is necessary to know the concept of school/university and their opinions about the concept. In Table 3 below, there is a distribution of students' collective memories and myths about their identity and school.

Table 3. Memory and myths of students regarding their self-identity and their schools

\begin{tabular}{|c|c|c|c|c|c|}
\hline Self-identity and school opinions & $\begin{array}{l}\vec{Z} \\
\overrightarrow{00} \\
\vec{\alpha} \\
\frac{\lambda}{0} \\
\stackrel{0}{\Xi} \\
0 \\
0 \\
0 \\
0\end{array}$ & $\begin{array}{l}\overrightarrow{\vec{C}} \\
\overrightarrow{\underline{\omega}} \\
\overrightarrow{\underline{\underline{x}}}\end{array}$ & 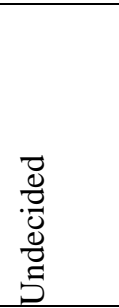 & $\stackrel{0}{\stackrel{0}{0}}$ & 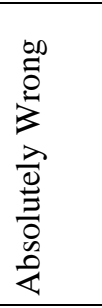 \\
\hline I am very happy to be a university student & $\% 57,1$ & $\% 32,9$ & $\% 4,6$ & $\% 4,7$ & $\% 0,7$ \\
\hline I am proud to express that I am a university student & $\% 56,7$ & $\% 30,9$ & $\% 4,4$ & $\% 6,7$ & $\% 1,3$ \\
\hline The studenthood period is the privileged period in my life. & $\% 50,3$ & $\% 29,5$ & $\% 9,4$ & $\% 7,4$ & $\% 3,4$ \\
\hline I don't want the studenthood period to end & $\% 36,6$ & $\% 24,1$ & $\% 16,8$ & $\% 10,7$ & $\% 11,8$ \\
\hline I miss my school during the holidays & $\% 37,3$ & $\% 31,3$ & $\% 16,0$ & $\% 7,4$ & $\% 8,0$ \\
\hline School is the place what makes me who I am & $\% 39,3$ & $\% 27,3$ & $\% 16,7$ & $\% 8,7$ & $\% 8,0$ \\
\hline
\end{tabular}


The learner, defined in this study as the identity of 'principal' and 'native', is fed from a memory that is assumed to be dominant among the student's multiple identities. For this reason, it is important to understand the participants 'self-identity convictions related to student life. Firstly, it is seen that a significant majority of the participants are satisfied with being university students (90\%). This indicator points to the conclusion that participants belong enough to want to have a strong relationship with the collective identity they carry. Likewise, a significant part of the participants $(87.6 \%)$ stated that they are proud to express that they are university students. Just as the myths that fill the ethnic loyalty and pride at the core of the diaspora reproduce themselves in the transfer of the learner to the linguistic plane with a similar pride myth. The myth of pride holds the stable discourses of the world of images shaped by the symbolism of the student and the belonging as above the symbols. These discourses are known for creating a 'sense of excellence' in people with the identity of a student. As a matter of fact, the majority of the participants (79.8\%) integrate their self-identity with the feeling of "excitement". Symbols in social life and their images also support this integrated feeling. However, in the case of 'profession ownership', which is a more distinguished identity in the continuation of this elitistness, students' opinions can be seen to be overestimated. For this reason, the participants 'opinion of not wanting to end their student identity is evident in the majority (36.6\%), ambivalence (16.8\%) and dissenting opinion $(11.8 \%)$, although they express themselves as a definite feeling. One of the symbolic details that should be understood from this clarity is that the participants want the better / next stage as an alternative to giving up their student identity.

The school/university, which gives the student identity card to which the participants are closely tied and which has the local characteristics of belonging, is the place that is missed even in a short-term break. The majority of the participants state that they miss the school even during a temporary separation period such as a holiday. The school does not define a reinforced concrete construction or a landscaped place here. The school is a symbolic area and myth, where memory for students is established, memories are built and gives the feeling of 'exclusivity'. School (39.3\%), as supported by the participants, is the place 'what makes me who I am for students.' The acceptance by the participants that school is a place that gives the student 'self' as a memory and myth does not make it surprising that being separated from it is interpreted as shaking, disintegrating, and breaking away from the 'self'. In Table 4 data distributions show the participants 'mental diaspora states regarding their disenfranchisement in the teleeducation process by moving away from the school giving their 'self-identity'.

Table 4. Students' self-perceptions of deterritorialization and mental diaspora in the tele-education process.

\begin{tabular}{|c|c|c|c|c|c|}
\hline $\begin{array}{l}\text { Self-perceptions of deterritorialization and diasporic } \\
\text { consciousness }\end{array}$ & 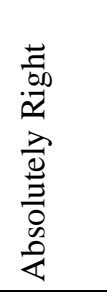 & 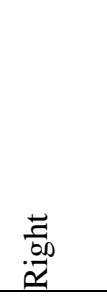 & 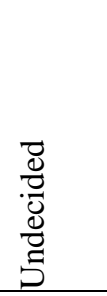 & $\stackrel{\infty}{\tilde{0}}$ & 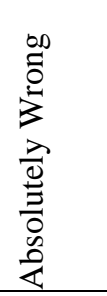 \\
\hline I feel like a forced immigrant. & $\% 40,7$ & $\% 28,0$ & $\% 8,7$ & $\% 18,7$ & $\% 4,0$ \\
\hline I feel disconnected from school. & $\% 40,0$ & $\% 27,3$ & $\% 9,3$ & $\% 18,0$ & $\% 5,3$ \\
\hline I feel disconnected from my friends. & $\% 38,7$ & $\% 32,0$ & $\% 10,0$ & $\% 16,0$ & $\% 3,3$ \\
\hline I think all the motivations of the students are scattered. & $\% 46,7$ & $\% 26,0$ & $\% 10,7$ & $\% 11,3$ & $\% 5,3$ \\
\hline I don't feel like a student. & $\% 35,3$ & $\% 23,3$ & $\% 17,3$ & $\% 16,0$ & $\% 8,0$ \\
\hline There is a social void in my life. & $\% 48,0$ & $\% 32,0$ & $\% 8,0$ & $\% 9,3$ & $\% 2,7$ \\
\hline There is a psychological gap in my life. & $\% 38,0$ & $\% 29,3$ & $\% 11,3$ & $\% 15,3$ & $\% 6,0$ \\
\hline I'm having identity crises when I'm away from school. & $\% 22,0$ & $\% 19,3$ & $\% 23,3$ & $\% 22,7$ & $\% 12,7$ \\
\hline I feel caught in the middle. & $\% 31,3$ & $\% 33,3$ & $\% 14,0$ & $\% 14,0$ & $\% 7,3$ \\
\hline
\end{tabular}


The fact that classes are on the internet causes me to be $\% 45,3 \quad \% 27,3 \quad \% 8,0 \quad \% 12,7 \quad \% 6,7$ physically and mentally divided.

Table 4 aims to see to what extent the participants will qualify their status in the tele-education process as diasporic, the proportion of those who consider themselves as forced immigrants $(68.7 \%)$ represents a significant majority. However, it should be noted that there is an undeniable group (18.7\%) opposing this majority view. This forced immigration feeling is a natural trigger for participants to feel as if they are disconnected from their schools (67.3\%) and friends (70.7\%) because immigration is the permanent state at the beginning and end of the territorial and social abandonment the break-up and the diaspora.

Another finding that the students were in the diaspora was that participants expressed a dominant opinion that there was a breakdown in all the motivations of the students who were part of this process (72.7\%). Moreover, the proportion of those who oppose this dominant view is remarkable in terms of its minority (16.6\%). The loss of origin in motivation, that is, mental belonging, is a sign of the loss of self-identity that gives students selectivity. While respondents expressed a dominant opinion that they did not feel like students (58.6\%), there was no significant majority of those who opposed this view (24.0\%). This data set, which shows that there are mental breakdowns in the learner's symbolic selfperception, informs the importance of the identity under which the diasporic consciousness is under siege. Under this siege, the awareness of social emptiness that arises in the life of the students is also supported by the participants $(80.0 \%)$. But the feeling of psychological emptiness (67.3\%), which further expands this social gap, emphasizes much more than a numerical expression of what participants are in the mental diaspora because the pandemic process, which threatens their physical health and initiates withdrawal from public spaces, becomes difficult to compensate for the trauma when it is integrated into the social and mental diaspora. The aims of tele-education as compensation may not match the actual practice.

The tele-education process in the pandemic, which prevents the perception of students as selfidentity, makes it a powerful problem to understand whether students are experiencing identity conflicts at the level of depression. But as a result of this effort, there can be no dominant response. Although participant responses are not sufficient to generalize the data on experiencing the crisis, the close proportional distribution seen in the table is actually a sign that the crisis is at the beginning with the phase of instability. Although there is no data set to justify the depression thesis, there is a sign of 'double absence' to support indirect problems. A significant proportion (64.6\%) of the respondents experience a state of 'purgatory', i.e., being in the middle, seen in the identity 'adventures of the diasporics.' The occasional stay of students, who can neither remain the same as before nor fully integrate into the new system, is one of the most productive sources of diasporic consciousness crises because of this area of belonging complements a meaningful image, with participants believing that they are physically and mentally divided (72.6\%) during the tele-education process. Mental and physical division, one of the strongest fuels of the mental diaspora, is the inevitable and paradoxical result of cognitive performances that go beyond the physical medium in relationships established by means.

\section{R. Q. 2. Do students strive to establish personal and indirect relationships and collective solidarity?}

The transplace ties, which fill an important gap in the sociology of migration and are among the essential parts of the diaspora, are the general definition of communicating with people from a distant homeland. Mass media brings those who are scattered in two distant places closer and keeps solidarity alive. The extent to which students care about transplace ties in order to maintain their perceptions of self-identity during the tele-education process supports the effort to understand whether they are in the 
diaspora. In this context, the responses to the questions that measure the tendency of the participants to maintain their personal and indirect relationships are shown in the data distribution in Table 5.

Table 5. Students' self-perceptions of transplace ties and the compensatory power of Tele-education

\begin{tabular}{|c|c|c|c|c|c|}
\hline Transplace ties and Tele-education considerations & 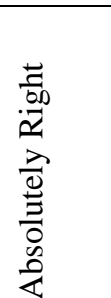 & \multicolumn{2}{|r|}{ 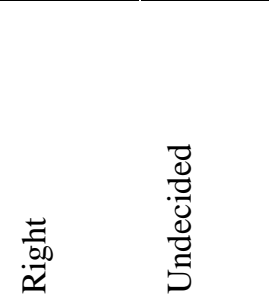 } & \multirow{2}{*}{$\frac{\overbrace{0}^{\infty}}{\%}$} & $\begin{array}{l}00 \\
\overline{0} \\
3 \\
3 \\
\frac{1}{0} \\
0 \\
0 \\
0 \\
0 \\
0 \\
\end{array}$ \\
\hline I keep in touch with my college friends on the internet. & $\% 46,0$ & $\% 50,0$ & $\% 1,3$ & & $\% 0,7$ \\
\hline I keep in touch with the lecturers on the internet. & $\% 11,3$ & $\% 49,1$ & $\% 22,6$ & $\% 9,4$ & $\% 7,5$ \\
\hline $\begin{array}{l}\text { Meeting with lecturers and friends on the internet increases } \\
\text { my student motivation. }\end{array}$ & $\% 28,3$ & $\% 41,5$ & $\% 13,2$ & $\% 9,4$ & $\% 7,5$ \\
\hline $\begin{array}{l}\text { Being in touch with friends and lecturers is good for my } \\
\text { sense of loneliness. }\end{array}$ & $\% 32,1$ & $\% 45,2$ & $\% 15,1$ & $\% 5,7$ & $\% 1,9$ \\
\hline $\begin{array}{l}\text { Being in touch with friends and lecturers is good for the } \\
\text { feeling of being scattered/dissipated. }\end{array}$ & $\% 41,5$ & $\% 43,4$ & $\% 11,3$ & $\% 1,9$ & $\% 1,9$ \\
\hline $\begin{array}{l}\text { Even though the Tele-education process continues, I feel } \\
\text { divided. }\end{array}$ & $\% 46,7$ & $\% 30,3$ & $\% 9,3$ & $\% 9,3$ & $\% 7,3$ \\
\hline $\begin{array}{l}\text { Tele-training lessons are good for the feeling of } \\
\text { disintegration in my mind. }\end{array}$ & $\% 8,0$ & $\% 17,3$ & $\% 28,0$ & $\% 27,3$ & $\% 19,3$ \\
\hline Tele-education classes make me feel like I'm in school. & $\% 9,3$ & $\% 16,7$ & $\% 21,3$ & $\% 23,3$ & $\% 29,3$ \\
\hline $\begin{array}{l}\text { Tele-education courses replace physical participation } \\
\text { courses. }\end{array}$ & $\% 6,7$ & $\% 10,0$ & $\% 13,3$ & $\% 25,3$ & $\% 44,7$ \\
\hline $\begin{array}{l}\text { Tele-education courses are more efficient than physical } \\
\text { participation courses. }\end{array}$ & $\% 5,3$ & $\% 8,0$ & $\% 13,3$ & $\% 27,3$ & $\% 46,0$ \\
\hline
\end{tabular}

As can be seen in the table, the participants, who are assumed to be in the diaspora and tested with this study, continue to meet with their friends from the university $(96.0 \%)$ and faculty members $(60.4 \%)$ via the internet (out of the tele-education process). This is not just to preserve the formal aspect of teleeducation, which indicates the over-bonding of the venue. At the same time, identities are kept alive through informal talks. According to this view, which is also supported by the participants, an important group $(69.8 \%)$ stated that meeting the faculty members and their friends on the internet increased their motivation and indirectly developed a compensation that would be good for the mental diaspora. These venue- over relationships have a direct effect on the feeling of loneliness (77.3\%) and the feeling of being scattered/dispersed ( $84.9 \%)$, as supported by the views of the participants. This situation, which supports and is supported by the assumption of the diaspora, is predictable in that it is among the inevitable pursuits of the scattered identity and its consciousness.

For students, the aspects of this desire to maintain space-extreme ties in diaspora form are related to feelings that are difficult to compensate with tele-education. As a significant number of respondents (78.0\%) stated, although tele-education is presented with a perception of continuity, it is obvious that the process is divided. Moreover, the success of this system, designed as a compensation, in implementing the compensatory role is also controversial. The respondents tend to be significantly ambivalent about how tele-education is good for the feeling of disorganization in their minds (28.0\%), while those who oppose the idea are the majority (46.6\%). This indicator may be a parameter for questioning the qualification condition of tele-education in creating compensations for the mental diaspora feeling. The reason is that even though tele-education was idealized with a perception that the 
process was going on, participants expressed the predominant opinion that they did not feel 'like they were in school' (52.6\%). When this view is combined with the view that tele-education courses are no substitute for physical lessons in school (70.0\%) and that tele-education courses are no more efficient than the courses in school (73.3\%), it becomes difficult to establish a compensatory relationship between the mental diaspora and tele-education.

\section{R.Q.3. Do students dream of going back to school/university?}

Among the characteristics that are looked at to identify the diaspora, perhaps the most striking one is 'dream of returning', and it is used to determine the differences between the scattered ones and the diaspora ones. Therefore, the 'come-back dream' can be considered as an indicator of whether students' identities are diasporic. The difference between students' dream of back to school/university or not sheds light on their self-identity as well as their diasporic carriers of consciousness. The data showing whether the participants have a dream of going back to school/university is shown in Table 6 below.

Table 6. Students' self-perceptions about their 'Back to School' dreams in the tele-education process

\begin{tabular}{|c|c|c|c|c|c|}
\hline Convictions for Going Back To School & 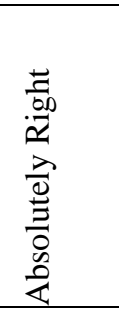 & 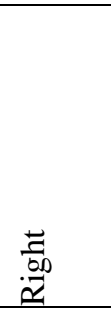 & 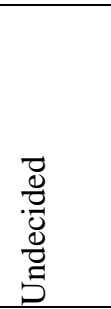 & $\frac{\infty}{3}$ & $\begin{array}{l}00 \\
\overline{0} \\
3 \\
3 \\
\frac{1}{2} \\
0 \\
0 \\
0 \\
0 \\
0 \\
\end{array}$ \\
\hline Even though it's tele-education, I feel like I'm on vacation. & $\% 18,7$ & $\% 30,0$ & $\% 14,0$ & $\% 22,0$ & $\% 15,3$ \\
\hline I miss school/I want to go back again. & $\% 45,3$ & $\% 36,0$ & $\% 6,7$ & $\% 6,0$ & $\% 6,0$ \\
\hline No school, no students. & $\% 49,3$ & $\% 24,7$ & $\% 8,7$ & $\% 10,0$ & $\% 7,3$ \\
\hline I'm worried I won't be able to go back to school. & $\% 43,3$ & $\% 21,3$ & $\% 10,0$ & $\% 20,0$ & $\% 5,4$ \\
\hline $\begin{array}{l}\text { I want Tele-education to continue instead of going back to } \\
\text { school. }\end{array}$ & $\% 14,0$ & $\% 8,7$ & $\% 13,3$ & $\% 24,7$ & $\% 39,3$ \\
\hline
\end{tabular}

A close relationship can be established between the proportion of participants (30.0\%) who think of their presence in tele-education in a holiday mode and the proportion of those who oppose this idea $(22.0 \%)$. It is clear that this condition is not a holiday mode. However, symbolically, it is possible to think that students can immerse themselves in a school-related come-back dream through this mode. Because the holiday is the journey to go back to its center, the students' feeling of holiday indicates that come-back consciousness is preserved. The main point is the high percentage of participants $(81.3 \%)$ who directly express that they miss the school/want to return. This rate is important in terms of clarifying the diasporic consciousness of the students as well as supporting the assumption of the study. In another question that connects students' desire to get back to school and tele-education, when a choice was made between the school and continuing tele-education, the participants preferred the school clearly $(64.0 \%)$ because a significant part of the participants (74.0\%) reported "No school, no students." The school that gives them the ability to become students is built and maintained with memory, just like the main dormitory that gives the person who is in the diaspora of his identity. This memory is one of the reasons why participants $(64.6 \%)$ who are worried that they cannot go back to school make up the majority compared to those who do not have such a concern (25.4\%). It can be thought that diasporic consciousness completes itself when this anxiety, which indicates that belonging is maintained, evolves into anxiety at the stage where non-belonging begins to emerge. As a matter of fact, the following final sub-problem test focuses on a concern that indicates a lack of belonging. 
R. Q. 4. Do students feel worried of belonging due to the lack of integration in their new environment where tele-education takes place?

The idea of belonging is important because identity is related to an origin. Students' concerns about their belonging and whether they can be mentally integrated into tele-education or not are similar to the concerns that diasporic migrants carry wherever they go. In Table 7 below, the distribution of the opinions of the participants regarding the belonging concerns in the tele-education process and the integration prevented by mental diaspora states are given.

Table 7. Students' self-perceptions of belonging concerns in tele-education process

\begin{tabular}{|c|c|c|c|c|c|}
\hline Students ' belonging concerns & 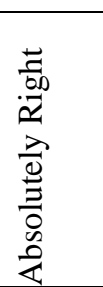 & 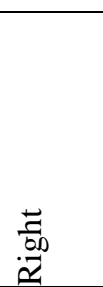 & 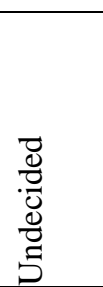 & ${ }_{5}^{\infty}$ & $\begin{array}{l}00 \\
0 \\
0 \\
3 \\
0 \\
0 \\
0 \\
0 \\
0 \\
0 \\
0\end{array}$ \\
\hline I'm worried about the uncertainty of the future & $\% 56,0$ & $\% 24,0$ & $\% 6,0$ & $\% 11,3$ & $\% 2,7$ \\
\hline $\begin{array}{l}\text { I'm worried about not being able to integrate into the Tele- } \\
\text { education system }\end{array}$ & $\% 38,0$ & $\% 23,3$ & $\% 18,7$ & $\% 14,7$ & $\% 5,3$ \\
\hline I'm worried about alienating the system & $\% 32,7$ & $\% 31,3$ & $\% 10,0$ & $\% 19,3$ & $\% 6,7$ \\
\hline $\begin{array}{l}\text { I'm worried about not being able to access the system/being } \\
\text { left out }\end{array}$ & $\% 41,3$ & $\% 24,7$ & $\% 8,7$ & $\% 17,3$ & $\% 8,0$ \\
\hline I'm worried about not knowing the system & $\% 28,7$ & $\% 27,3$ & $\% 11,3$ & $\% 23,3$ & $\% 9,3$ \\
\hline $\begin{array}{l}\text { I'm worried about not being able to keep up with the culture } \\
\text { in the system }\end{array}$ & $\% 27,3$ & $\% 31,3$ & $\% 12,0$ & $\% 20,7$ & $\% 8,7$ \\
\hline
\end{tabular}

A high proportion of participants stated that, like immigrants who are in diaspora, they are 'concerned about the uncertainty of the future' (80.0\%). Like a journey with an uncertain ending, diaspora is the biggest obstacle for students to act with an integrated consciousness to the system. Indeed, the overwhelming majority of the participants $(61.3 \%)$ directly express this concern.

As seen in another measurement parameter that introduces the mental diaspora states of the participants, the 'the worry of alienation.' seen in diasporic immigrants is dominant (64.0\%). This dominance is also a precursor of how to stay away from the school where the sense of 'locality' is produced and how the presence in tele-education will be shaped. The fact that the student continues to be in a digital environment where sthe feels like a stranger instead of a school where sthe feels like a native has the risk of causing student awareness to settle as a diasporic consciousness. For this reason, the majority of the participants are concerned about not knowing a foreign place tele-education system (56.0\%), exclusion (66.0\%) and inability to keep up with the culture there (58.6\%). These concerns can be coded as undoubted findings in determining the state of diaspora because the diasporic individual is known for its foreignness, exclusion, and marginal existence that cannot keep up with culture. It should be noted that the alarming online behavior of students in tele-education processes involves a degree of marginality that cannot be explained only by concentration behavior.

\section{Conclusions}

The findings prove that 'the students' transition into diaspora during the compulsory education due to the pandemic and that the tele-education process is not effective enough in compensating for diasporic consciousness or even risks triggering the state of the mental diaspora have been found as the founding 
assumption of this study. Data on sub-problems determined to test the basic assumption and measuring whether students are in the diaspora or not strongly supported and expanded the existence of the diaspora metaphor. As a result, the view that students are in the mental diaspora and the tele-education process keeps many sub-problems hidden in itself is defensible.

The mental diaspora state, which finds the ground to naturally occur as a result of the physical diffuse detected by the research, is not in a single form. The mental diaspora, whose many variants emerged through the flexible infrastructure and multiple models of the digital system, has been identified in this study in three types. The first is the 'diasporic consciousness' state, which is the traumatic cognition of diffusion. The mental state, psychological conditions, and anxiety-oriented expectations of the students are examples of this situation. The second is the physical and mental distinction. As the instrumental interaction (CMC) of students increases, the problem of division that they encounter increases the prevalence of mental diaspora. The student may fail to recover the division between herlhis mind and herlhis organic being, which is abstracted from herlhis physical environment and is reorganized in the digital environment. The third is cognitive disintegration and unwarranted disaffection of the deterritorialization mind. The student's mind can be shaped by a large number of digital fractions that are related or unrelated to each other and may lose their reflexes and cease to feel belongingness. As determined by the participants, the majority of the students cannot mentally predict their position in the tele-education process and the position they can separate themselves and are surrounded by a fluid consciousness.

The notion of diaspora, which transcends the local boundaries with reference to the 'online traveler' characteristics of modern diasporically unwarranted students (usually from Generation Z), can ultimately break with physicality because diaspora, as a sociological derivative of students' 'forced migration', symbolizes the separation, fragmentation, and dispersion from the homeland (school) as well as in the mental phase, which includes the division between physical/organic and digital/inorganic existence (Baudrillard, 2005; Elitaş \& Keskin, 2014) reconceptualizes. Online traveling in absolute flow with mobility/mobilization (Boichak, 2019) as a result of the mental and physicality of individuals in the diaspora who leave their diasporic filled the main venues of the reorganized cognitive screens, with their diasporic identities and transnational networks invalidates wrapped vernacular (Baubock \& Faist, 2010).

The fact that instrumental and cultural convergence accelerates the transformation of local media into global media (Karim, 1998) and the new digital presence of the diaspora that creates extra-locational interlocks among transnational communities (Bruneau, 2010), students have to maintain their traditional education relations as 'tele'. It is also a sign that they are qualified digital diasporic individuals. Indeed, social media is a 'different ' place, and even if it is within national borders, its location is unpredictable, and it accepts participants on the condition of emigration/travel. Social media along with 'mediums' and mediatic instruments entwining everyday life with mobilized functions (Athique, 2011), increased mobility through mental and socio-digital labor, if not physicality, reinforces the diasporic identity of the $\mathrm{Y}$ and $\mathrm{Z}$ generation students.

New media-related virtual community derivatives, called the digital diaspora (Anderson, 2019), are known for establishing empathetic networks among the audience of homogeneous media, unlike classic diaspora broadcasting. For this reason, names that evoke new media such as e-diaspora, net diaspora, web diaspora, and online diaspora (Ponzanesi, 2020) are also adopted. These names help to understand what kind of diasporic panorama is part of the parties who want to maintain their educational-based community ties using the internet infrastructure. Moreover, this kind of life has become an indispensable slice of recreational pleasures and meaningful media activities in which the "new normal" is represented as deterritorialization due to the fact that not only the pandemic world but "normal" life also turns into a routine among everyday styles (Georgiou, 2013). 
The future role of CMC as a reflection in education is discussed; (Koltuk \& Kocakaya, 2016; Bull \& Kadjer, 2004; AlNoamany et al., 2016) and evaluated as a technological tool is powerful (Robin, 2008) 'digital storytelling', is planned to be integrated into the physical classroom environment, while instrumental design (Lewin, 2011), tele-education has shown efficacy across courses in the process. Digital storytelling, which discusses opportunities and threats after the rise of digital resources and multimedia opportunities, refers to the use of multimedia instruments to create narratives/stories about lesson-related content, according to Robin (2012). This method, which describes producing narratives by using video, audio, photography, and other smart computer technologies together, can be examined in three types (Robin, 2011): 'personal, historical and informative'. The education, which uses informative digital storytelling, aims to narrate the lessons and tell students through digital tools. Video, audio, photography, and virtual classroom activities in telemedicine mean a narrative synergy between faculty members and students. Thus, the process's physical diaspora becomes complex at the instrumental level due to the mental division/dispersion mode. In fact, in trans-media narration (Jenkins, 2007), which is a form of digital storytelling within the scope of CMC, there is a more complicated result such that content is not meaningful alone and all the content that spreads partly throughout the process builds meaning together. Due to this complexity, the possibilities of mental connection between the contents increase and narrow on the other.

\section{Ethics Committee Approval}

The author(s) confirm(s) that ethical approval was obtained from Bayburt University (Approval Date: 19/11/2020).

\section{References}

Africa-Europe Platform (2014). Diaspora organisations as strategic agents of development. Retrieved from https://www.diaspora-centre.org/DOCS/EADPD/24022014EADPD-Report-def.pdf. (Accessed date: 15.07.2020).

Ahmed, H. \& Bradford, S. (2011). Constructing education as human capital in a transitional society: A case study of Somaliland's education reconstruction. Research in Comparative and International Education, 6(2), 236-249.

AlNoamany, Y, Weigle, M. C. \& Nelson, M. (2016). Characteristic of social media stories. International Journal on Digital Libraries, 17(3), 239-256.

Anderson, K. B. (2019). Digital diasporas: an overview of the research areas of migration and new media through a narrative literature review. Human Technology, 15(2), 142-180.

Anteby-Yenini, L. \& Berthomiere, W. (2005). Diaspora: A look back on a concept. In L. Anteby \& G. Sheffer (Eds.). 2000s ang de diasporas (pp. 132-134). Rennes: Presses Universitaries de Rennes.

Athique, A. (2011). Diasporik Audiences and non-resident media: The case of India films. Journal of Audience and Reception Studies, 8(2), 1-23.

Bauböck, R. \& Faist, T. (2010). Diasporas and transnationalism: Concepts, theories and methods. Amsterdam: Amsterdam University Press.

Baudrillard, J. (2005). The intelligence of evil or lucidity pact. Chris Turner (Trans.). Oxford: Oxford International Publishers. 
Bekerman, Z. (2020). Diaspora, Indigenous and Minority Education: Studies of Migration, Integration, Equity and Cultural Survival. New York: Routledge.

Ben-Rafael, E. (2013). Diaspora. Current Sociology, 61(5-6), 842-861.

Boichak, O. (2019). Mobilizing diaspora: understanding transnational relief efforts in the age of social media. $52^{\text {nd }}$ Hawaii International Conference on System Sciences Proceeding Book, 2792-2801.

Boutte, G., Johnson, G. L., Wynter-Hoyte, K., \& Uyoata, U. E. (2017). Using Africa diaspora literacy to heal and restore the souls of young black children. International Critical Childhood Policy Studies, 6(1), 66-79.

Bruneau, M. (2010). Diasporas, transnational spaces and communities. In R. Bauböck \& T. Faist (Eds.). Diasporas and Transnationalism: Concepts, Theories and Methods (pp. 35-50). Amsterdam: Amsterdam University Press.

Bull, G. \& Kajder, S. (2004). Digital storytelling in the language art classroom. Learning and Leading with Technology, 32(4), 46-49.

Carlson, W. L. \& Hong, S. (2011). The Haitian diaspora \& education reform in Haiti challenges \& recommendations. Retrieved Hrom https://www.haiti-now.org/wpcontent/uploads/2017/05/Education-Reform-in-Haiti-Challenges-Recommendations-ColumbiaMay-2011.pdf (Accessed Date: 15.07.2020).

Castells, M. (2000) The rise of the network society. In M. Castells (Ed.), The Information Age: Economy, Society and Culture (pp. 44-46). Malden: Blackwell Press.

Castells, M. (2008). A ğ toplumunun yükselişi. Ebru Kılıç (Trans.). İstanbul: İstanbul Bilgi Üniversitesi Yayınları.

Cohen, R. (2008). Global diasporas: An introduction. London \& New York: Routledge.

Cohen, R. (1996). Diasporas and the state: From victims to challengers. Retrieved from https://warwick.ac.uk/fac/soc/sociology/staff/cohenr/research/papers/diasporas.pdf (Accessed Date: 15.07.2020).

Cortegiani, A., Ingoglia, G., Ippolito, M., Giarratano, A., \& Einav, S. (2020). A systematic review on the efficacy and safety of chloroquine for the treatment of Covid-19. Journal of Critical Care, 57, 279-283.

De Leeuw, E. D., Hox, J. J., \& Dillman, D. A. (2008). International handbook of survey methodology. Routledge.

Deleuze, G. \& Guattari, F. (2005). A thousand plateaus: capitalism and schizophrenia. Brian Massumi (Trans.). $12^{\text {th }}$ Edition. London and Minneapolis: University of Minnesota.

Di Gennaro, F., Pizzol D., Marotta, C., Antunes, M., Racalbuto, V., Veronese, N. \& Smith, L. (2020). Coronavirus diseases (Covid-19) current status and future perspectives: A narrative review. Environment Research and Public Health, 17(8), 2690.

Elitaş, T. (2018). Uzaktan eğitim ve yeni iletişim teknolojileri. İstanbul: Cinius Yayınları.

Elitaş, T. \& Keskin, S. (2014). Sanal aidiyet bağlamında zihinsel diaspora: Facebook örneği. Atatürk Üniversitesi Illetişim Dergisi, 7(1), 161-186.

Elitaş, T. \& Devran, Y. (2017). Yeni iletişim teknolojilerinin uzaktan eğitime entegrasyonunda sanal sınıf ortamları: ATAUZEM örneği. Manas Sosyal Araştırmalar Dergisi, 6(2), 213-225. 
Ferede, M. K. (2020). Policy brief: Engaging the diaspora: Potential for sub-Saharan African Universities Programme on Innovation, Higher Education and Research for Development IHERD. Retrieved from https://www.oecd.org/sti/Engaging\%20the\%20Diaspora_Ferede.pdf. (Accessed Date: 15.07.2020).

Georgiou, M. (2013). Diaspora in the digital era: Minorities and media representation. Journal on Ethnopolitics and Minority Issues in Europe, 12(4), 80-89.

Göker, G. (2015). Göç, kimlik, aidiyet: kültürlerarası iletişim açısından İsveçli Türkler. Konya: Literatürk Yayınları.

Grooms, L. D. (2003). Computer-Mediated Communication: A vehicle for learning. International Review of Research in Open and Distance Learning, 4(2), 1-16.

Habermas, J. (1993). İdeoloji olarak teknik ve bilim. Mustafa Tüzel (Trans.). İstanbul: Yapı Kredi Yayınları.

Heidegger, M. (2011). Varlık ve zaman. Kaan H. Ökten (Trans.). İstanbul: Agora Kitaplığı.

Hosein, R., Franklin, M. \& Joseph, S. C. (2006). The Caribbean diaspora: an untapped resource for impacting economic development through investment in the Caribbean. Retrieved from https://sta.uwi.edu/conferences/09/salises/documents/m\%20franklin.pdf. (Accessed Date: 15.07.2020).

Hrastinski, S. \& Keller, C. (2007). Computer-Mediated Communication in education: A review of recent research. Educational Media International, 44(1), 61-77.

Jackson, M. O. (2005). A survey models of network formation: Stability and efficiency. In G. Demange \& M. Wooders (Eds.), Group formation in economics: Network, clubs and coalitions (pp. 11-57). Cambridge: Cambridge University Press.

Jenkins, H. (2007). Transmedia storytelling 101. Retrieved from http://henryjenkins.org/blog/2007/03/transmedia_storytelling_101.html. Accessed Date: 15.07.2020.

Karim, K. H. (1998). From ethnic media to global media: Transnational communication networks among diasporic communities. International Comparative Research Group Strategic Research and Analysis, June (1998), 1-23.

Keskin, S. \& Kaya, U. (2018). Sosyal ağ otobanlarının otostopçuları: Interrail Türkiye topluluğunda gezgin kültürü. In M. Gökhan Genel (Ed.), Iletişsim çağında dijital kültür (pp.14-25). Konya: Eğitim Yayınevi.

Koltuk, N. \& Kocakaya, S. (2016). Researching and evaluating digital storytelling as a distance education tool in physics instruction: An application with pre-service physics teachers. TOJDE, 17(1), 87-99.

Lewin, T. (2011). Participatory learning and action. In T. Lewin (Ed.), Digital storytelling (pp. 62-74).

Lulle, A. (2015). Creating opportunities for development: diaspora children and youth. Retrieved from https://www.lu.lv/fileadmin/user_upload/lu_portal/projekti/diaspora/petijumi/Diaspora_children_a nd_youth_conceptual_introduction_Lulle_2015.pdf. (Accessed Date: 15.07.2020).

Manfreda, K. L. \& Vehovar, V. (2008). Internet surveys. In E. D. De Leeuw, J. J. Hox \& D. A. Dillman (Eds.). International Handbook of Survey Methodology (pp. 264-284). Jena: EAM.

Manovich, L. (2001). The language of new media. Cambridge: MIT Press. 
Mcluhan, M. \& Power, B. R. (2010) Global köy. Bahar Öcal Düzgören (Trans.) İstanbul: Scala.

Nadeem, S. (2020). Coronavirus Covid-19: Available free literature provided by various companies, Journals and Organizations around the World Journal of Ongoing Chemical Research, 5(1), 7-13.

NTV (2020). İbrahim Kalın: Okullar pazartesiden itibaren tatil (Okullara Corona virüs tatili) https://www.ntv.com.tr/turkiye/ibrahim-kalin-okullar-pazartesiden-itibaren-tatil-okullara-coronavirus-tatili,AfGTlqrbP0KDSx_hf6CSrw

Ponzanesi, S. (2020). Digital diasporas: Postcoloniality, media and affect. International Journal of Postcolonial Studies, 22(8), 1-18.

Ramessur, R. T. \& Santally, M. I. (2007). Computer-Mediated Communication for effective teachinglearning of coastal zone management module. IJEDICT, 3(1), 116-125.

Roberts, M. E., Stewart, B. M., Tingley, D. (2014). Structural topic models for open-ended responses. American Journal of Political Science, 58(4), 1-19.

Robin, B. R. (2011). The educational uses of digital storytelling, Retrieved from http:// digitalliteracyintheclassroom.pbworks.com/f/Educ-Uses-DS.pdf, (Accessed Date: 15.07.2020).

Robin, B.R. \& S. G. McNeil, S. (2012). What teachers should know about digital storytelling, Digital Education Review, 22, 37-51.

Robin, B. (2008). Digital storytelling: A powerful technology tool for the 21 st century classroom. Theory into Practice, 47, 220-228.

Safran, W. (1991). Diasporas in modern societies: Myths of homeland and returns. Diaspora: A Journal of Transnational Studies, 1(1), 83-99.

Sinclair, J. (2016). Media and diaspora. In P. Rizova \& A. D. Smith (Eds.), The Willey Blackwell encyclopedia of race, ethnicity and Nationalism (pp. 77-99). New Jersey: Willey-Blackwell.

Şahin, A. R., Erdoğan, A., Ağaoğlu, P. M., Dineri, Y. Çakırc1, A. Y., Senel, M. E., Okyay, R. A. \& Taşdoğan, A. M. (2020). 2019 Novel Coronavirus (Covid-19) outbreak: A review of the current literature. EJMO, 4(1), 1-7.

Ulusoy, E. (2016). Diasporayı yeniden düşünmek: Diaspora teorisi bağlamında Türkiye'nin diaspora politikası. Ankara: Pegem Akademi.

Ulusoy, E. (2017). Diaspora kavramı ve Türkiye'nin diaspora politikalarının modern teori çerçevesinde sosyo-politik bir analizi. Insan ve Toplum, 7(1), 139-160.

Unhale, S. S., Ansar, Q. B., Sanap, S., Thakhre, S. Wadatkar, S. Bairagi, R. Sagrule, S. \& Biyani, K. R. (2020). A review on Corona Virus (Covid-19). World Journal of Pharmaceutical and Life Sciences, 6(4), 109-115.

World Health Organization (2020a). What is the WHO definition of health? Retrieved from https://www.who.int/about/who-we-are/frequently-asked-questions (Accessed Date: 11.05.2020).

World Health Organization (2020b). Coronavirus disease 2019 (Covid-19) Situation Report - 50. Retrieved From Https:/Www.Who.İnt/Docs/Default-Source/Coronaviruse/SituationReports/20200310-Sitrep-50-Covid-19.Pdf?Sfvrsn=55e904fb_2 (Accessed Date: 11.05.2020).

World Health Organization (2020c). Mental health and psychological resilience during the COVID-19 pandemic. Retrieved from http://www.euro.who.int/en/health-topics/healthemergencies/coronavirus-covid-19/news/news/2020/3/mental-health-and-psychological-resilienceduring-the-covid-19-pandemic (Accessed Date: 11.05.2020). 
Yaldız, F. (2013). Diaspora kavramı: Tarihçe, gelişme ve tartı̧̧malar. Hacettepe Üniversitesi Türkiyat Araştırmaları Dergisi, 2(18), 289-318.

Yavuz, S. Ş. \& Ünal, S. (2020). Antiviral treatment of Covid-19. Turkish Journal of Medical Sciences, 50(20), 611-619.

YÖK (2020) Yök'ten, Salgın Sürecinde Üniversitelerdeki Uzaktan Eğitimin Bir Aylık Durum Tespiti YÖK'ten, Salgın Sürecinde Üniversitelerdeki Uzaktan Eğitimin Bir Aylık Durum Tespiti.

Retrieved from https://www.yok.gov.tr/Sayfalar/Haberler/2020/uzaktan-egitime-yonelikdegerlendirme.aspx?fbclid=IwAR2KzZwUqqjE6InsGV1Ocbtz8pWDimPhI6arTMYEbVss2YtjuM UOs7WBrN

Yusuf, M. H. (2012). The impact of diaspora in educational development in their homeland: The case of Somaliland (Unpublished doctoral dissertation). Norwegian University of Life Sciences, Ås, Norway.

\title{
Türkiye'de COVID-19 pandemi sürecinde ‘tele-eğitim': Türkçe Öğretmenliği
}

\author{
öğrencileri özelinde bir zihinsel diaspora araştırması
}

\section{$\ddot{O} \mathbf{z}$}

Bu çalışma, COVID-19 pandemisinin olağan dışı tarihinde dönüşmek ve yeni normal ile uyum sağlamak zorunda olan eğitim süreçlerini ilişkisel ve metaforik bir yaklaşımla haritalamaya çalışmaktadır. Çalışmada pandemi itkisiyle gerçekleşen zorunlu 'eve dönüş' nedeniyle coğrafik olarak 'saçılan/dağılan' öğrencilerin mevcut fiziksel ve zihinsel kondisyonları, 'diaspora' metaforuyla kavramsallaştırılmaktadır. Çalışma, kesintiye uğrayan eğitsel ilişkileri telafi etmek ve yeniden sürdürülebilir yapmak için tasarlanan tele-eğitim süreçlerinin işlevselliğini sorgulayarak öğrenci merkezli sosyal sorunlara dikkat çekmeyi hedeflemektedir. İnsan bilgisayar etkileşimi ve bilgisayar aracılı iletişimin yersiz-yurtsuzlaştırdığı çevrimiçi bilincin, öğrencilik performanslarına etkilerini ölçmek ve tele-eğitim sürecindeki öğrenci motivasyonlarını anlamak için Türkiye'deki 10 üniversiteden 150 öğrencinin katıldığı bir anket çalışması yapılmıştır. Çalışmanın sonuçları, tele-eğitim sürecindeki öğrencilik hallerinin diasporik kimlikle örtüştügünü ve tamamıyla telafi üretemeyen bu olağandışı teknoloji entegrasyonunun zihinsel diaspora hislerini tetiklediğini göstermektedir.

Anahtar sözcükler: COVID-19; pandemi; uzaktan eğitim; Türkçe Öğretmenliği; zihinsel diaspora

\section{AUTHOR BIODATA}

Mete Yusuf Ustabulut works at Bayburt University.

Savaş Keskin works at Bayburt University. 